\title{
TELL-ING IT LIKE IT IS: Practical implications from a critical stance on technology-enhanced language learning
}

\author{
Adriana Raquel Díaz ${ }^{1}$ \\ School of Languages and Cultures, The University of Queensland (Australia) \\ Hugo Hortiguera \\ School of Languages and Linguistics, Griffith University (Australia)
}

\begin{abstract}
This paper presents a critical stance in the face of the technology-enhanced language learning (TELL) hype in higher education (HE). This hype, largely driven by institutional - instrumental and financial - imperatives has come under increasing scrutiny in recent times. Indeed, emerging discourses surrounding the broader context of technology-enhanced learning question the focus on technology-led innovation rather than pedagogy-led innovation as well as a number of scholarly aspects that remain largely undertheorised (cf. Bayne, 2014; Kirkwood \& Price, 2013, 2014). In this paper we thus set out to articulate the challenges we face as language educators in the HE context and, in so doing, bring to light the glaring methodological gap that emerges from these. This discussion is complemented by practical examples from ongoing curricular innovation in intermediate Spanish language courses. These practical examples - drawn from an Action Research-driven pedagogic intervention on the use of PowerPoint in Spanish as a second/foreign language - illustrate the pedagogical strategies we have implemented to respond to these challenges critically, but also, creatively. These strategies integrate theoretical principles from cognitive grammar (cf. Llopis-García,
\end{abstract}


2011) and an affective engagement approach (cf. Arnold, 2000) to address specific pedagogical concerns that have emerged in these courses.

Keywords: technology-enhanced language learning, cognitive grammar, Spanish.

\section{Resumen}

Este artículo presenta una postura crítica frente al discurso hiperbólico potenciado por el uso de la tecnología en el aprendizaje de idiomas (TELL), específicamente, en el contexto universitario. Este discurso, impulsado en gran medida por las exigencias institucionales de carácter instrumental y financiero ha sido objeto de un intenso escrutinio en los últimos tiempos. Concretamente, este discurso ha sido cuestionado por su tendencia a centrarse en un enfoque de la innovación dirigido por tecnología en lugar de la innovación dirigida por la pedagogía, así como por una serie de aspectos académicos que siguen, en gran medida, escasamente estudiados (cf. Bayne, 2014; Kirkwood \& Price, 2013, 2014). En este trabajo nos propusimos articular los desafíos que enfrentamos como educadores de lengua en el contexto universitario y poner así en evidencia la brecha metodológica que se desprende de estos. Esta exposición teórica se complementa con ejemplos prácticos de innovación curricular en cursos de español a nivel intermedio. Estos ejemplos prácticos - derivados de un proyecto investigación-acción sobre el uso de PowerPoint en la clase de español como segunda lengua/ lengua extranjera -ilustran las estrategias pedagógicas que hemos implementado para responder a estos desafíos, no solo de manera crítica sino también creativa. Estas estrategias integran los principios teóricos de la gramática cognitiva (cf. LlopisGarcía, 2011) y un enfoque en la dimensión afectiva del aprendizaje (cf. Arnold, 2000) que nos sirvieron para abordar las preocupaciones pedagógicas que han surgido en estos cursos.

Palabras claves: aprendizaje de idiomas potenciado por la tecnología, gramática cognitiva, español.

\section{Introduction}

“¿Por dónde empiezo? (Where do I start from?)"

This is a question a fellow language teacher anxiously asked us as she succumbed to the pressure from her institution to reduce teaching contact hours while substantially increasing the number of students in each of her of classes and thus felt compelled to consider the integration of 'technology' as a potential tool to mitigate the repercussions these extreme measures may have on the quality of language learning and teaching. She pressed on with her questioning: "Can technology really help us optimise our teaching-learning process under these conditions? And if so... HOW?" These questions may resonate with many of us as they bring to light an increasingly glaring juxtaposition. While the hype to integrate technology in our classrooms is on the rise, the pedagogical, scholarly-based articulation of technology-assisted 
innovation in university teaching and learning remains largely uncharted (Kirkwood \& Price, 2013, 2014). This is particularly the case in modern/foreign language learning, a field which, despite a relatively young but robust history in technology-assisted pedagogical and empirical work, remains largely trapped in a methodological gap (see Blake, 1998; Blake, 2000, 2001, 2006, 2007, 2008, 2010; and also Dooly \& Masats, 2015, for a review of research conducted in Spain, specifically, their section on research in the use of TELL; and Gimeno-Sanz, 2015; Golonka, Bowles, Frank, Richardson, \& Freynik, 2012; González, 2012; and Liu, Moore, Graham, \& Lee, 2002, for comprehensive reviews on relevant research at international level; see also Román-Mendoza, 2014, for a detailed review of the situation in the United States of America, especifically concerned with the teaching of Spanish as a second/foreign language).

In this paper we aim to articulate key challenges involved in the pedagogicallydriven integration of technology in today's university language classrooms. In so doing, we take the non-specialist/non-expert teacher/practitioner's perspective. In other words, we acknowledge that while many colleagues/readers are language teacher-researchers specialising in the area of Computer Language Assisted Language Learning (CALL) - or its more recent moniker, Technology-Enhanced Language Learning (TELL), we argue that it is mainly the non-specialist teacher/practitioner - and, in many cases, nonspecialist casual staff in higher education (HE) institutions (cf. Nettelbeck, Hajek, \& Woods, 2012) - that are in desperate need of practical ideas, just like the colleague that posed the opening question. We have grouped these challenges under four interrelated categories, two of which can be viewed from the top-down: 1) prevalence of technology-boosting discourses; 2) precarious situation of languages in $\mathrm{HE}$; and two which can be viewed from the bottom up: 3) new learner profiles and 4) a widening methodological gap, concerned with the availability of technology-enhanced teaching materials or lack thereof - as well as with the need for further teacher education. While these challenges may resonate at international level, and indeed, the supporting literature provided spans across continents, we focus specifically on the Australian HE context.

This paper is divided into three main sections; we start by charting the territory, and in so doing, exploring the four aforementioned challenges. The second section of the paper is devoted to the description of our specific teaching context and the ways in which these challenges have materialised. In this section we provide practical examples of the pedagogical strategies we have implemented to meet these challenges. The third and final section of the 
paper provides a roadmap to help other non-specialist colleagues to critically conceptualise, design and implement pedagogically-situated strategies of their own.

\section{Theoretical framework: A critical stance in the face of 'technology'}

For us, positioning ourselves within a critical stance means questioning the very conditions under which Information and Communication Technologies $(\text { ICTs })^{2}$ seek to be integrated in our practices as language educators. This critical stance is not new; however, we argue that numerous scholars' voices have started to unify to articulate new understandings of what this critical stance may entail (Bayne, 2014; Bulfin, Johnson, \& Bigum, 2015; Clegg, Hudson, \& Steel, 2003; Henderson \& Romeo, 2015; Selwyn, 2007, 2013, 2015a, 2015b). We believe that the echo of these voices is starting to grow and capture the attention of educators in general, and in our case, language educators in particular (cf. Dooly, 2015). These voices call for us to 'wake up' from the 'technological somnambulism' (Winner, 2013) that, as explained by Selwyn (2013, p. 3) consists in "the tendency for a majority of people to sleepwalk through mediations with technology". Our critical stance in this paper consists in critically articulating the challenges we face and providing our own pedagogically situated response.

\section{Prevalence of technology-boosting discourses}

Already at the turn of this new century, Clegg, Hudson and Steel (2003) had identified the determining effect of the discursively 'cyperbolic' language used to frame the potential impact of integrating ICTs in HE. More than ten years later, little has changed (cf. Selwyn, 2015a). Big claims about the nature of ICTs as 'disruptive', 'revolutionising', 'game changing' are just a few examples of the rhetoric that nowadays fill the pages of our institutions' academic plans, where our educational mission, goals, principles and aspirations are spelt out.

Indeed, the widespread myth, deeply entrenched in HE policy discourse suggests that the mere inclusion of ICTs could "transform" our teaching so as to prepare our students for an information-driven labour market. Institutions claim that in order to remain competitive in the future employment market, our students must be exposed to technology 'enhanced' learning

In this paper we use the acronym ICT as an umbrella term to refer to a wide range of computermediated learning tools which may also be understood as a key component in the fie 
environments. This strictly instrumental goal has replaced the more basic, modest and once considered important aspirations of promoting learning as form of enrichment in itself.

This rhetoric seems to be driven by the belief that "digital technologies herald distinctively new and improved" ways of teaching and learning "in comparison to preceding 'predigital' times" (Selwyn, 2013, p. 5). In this context, the very word 'enhanced' should also be brought to question since, as Bayne (2015) suggests, it assumes that there is "a pre-existing set of practices which are not in any need of radical shift or displacement, but are rather simply open to being made even 'better' by the judicious application of a little (in this case technological) assistance" (p. 10). Furthermore, this rhetoric seems to doubt and, ultimately, cast-off so-called 'traditional' educational environments, compelling us to overhaul our teaching practices. Ultimately, this rhetoric seems to suggest that more conventional teaching approaches have failed to prepare learners to satisfactorily perform or operate in the workplaces of today's society and that a change is desperately needed. Generally speaking, as Kirkwood and Price (2014, p. 9) point out, "senior managers and decisionmakers are likely to be interested in efficiency benefits that contribute to the reduction or containment of costs, increasing student numbers, competitive advantage, or meeting student expectations." On the other hand, teaching practitioners are more likely to be interested in potential transformational benefits, i.e., "in cognitive gains of individual learners" (Bayne 2014, p. 11). Pedagogy is reduced then to a matter of employment training in which a performance-based, market-driven conceptualisations of learning prevails (Giroux \& Myrsiades, 2001).

These discourses are reinforced by a rhetoric of immediacy which has also infiltrated HE policy decisions. This rhetoric stresses the needs to offer "more options" for studying online, either totally or partially, anytime, anywhere. In this context, "flexibility" is a ubiquitous term understood in terms of the accessibility, delivery, pace and distribution of learning (Fevolden \& Tømte, 2015).

Along with HE institutions, the publishing industry is another stakeholder whose interests are being shaped and - at the same time - are helping to shape these discourses by making claims regarding their potential to address these needs. With the ever-evolving changes in the marketplace, publishers are constantly exploring new ways to develop innovative solutions for maintaining a competitive lead in authorship and intellectual capital. Seeking new business opportunities outside the traditional printed textbook space in order to create new revenue streams seems to be the next step in an industry 
that is struggling to survive in an environment where everything is becoming "virtual" - and second-hand textbooks abound. And so, they resort to similar "cyperbolic" language that echoes university's rhetoric to 'seduce' teachers into adopting their products: "Our tool X engages students and assists them in their learning process outside the classroom, improving memory, increasing students' attention and retention, teaching effectiveness, learning efficiency and, of course, better career readiness".

A clear example of this situation is the recent strategy developed by McGraw Hill. Instructors can engage students through the new Connect platform belonging to McGraw Hill (cf. Bowen \& Lack, 2012). In it, they can find online versions of the textbooks, accompanied by several interactive features like the LearnSmart software which, with the help of adaptive learning technology, can almost be compared to a personal (virtual) tutor (see Cubillos, 2014 for emerging trends of this kind with Spanish language textbooks in the United States). In order to gain complete access to this "new experience", however, these textbooks come with access codes that can be purchased separately and that expire at the end of the academic semester (or every two years). In the Australian context, this has serious implications in terms of equitable access to learning resources and assessment.

Ultimately, we need to be aware of the ideological nature underlying the rhetoric utilised by various stakeholders. Here, in Selwyn's words, we are exhorted to question, unpack and problematise, "the inherently political nature of what is seen usually as a profoundly apolitical aspect of contemporary education provision and practice" (2013, p 5). Some questions that we may ask are:

[W] hy have [certain] forms of technology use been selected and promoted in the ways that they are? Whose technologies are these? Who selected them? Why are they being organized and provided in the ways that they are? What interests are benefiting from this use? What linkages are there between these forms of educational technology and wider societal (re)arrangements and organization? (Selwyn, 2013, p 4)

Set against this background we find a field at risk; a field whose vulnerable position is also deeply entrenched in the very discourses and rhetoric that support a neoliberal, instrumentalist, corporate view of education (Bernstein, Hellmich, Katznelson, Shin, \& Vinall, 2015). 
Precarious situation of modern/foreign languages in $\mathrm{HE}$

As discussed in earlier paragraphs, internationalisation processes in HE are largely focused on preparing graduates for an increasingly globalised world (Egron-Polak \& Hudson, 2010). Yet, as highlighted by Díaz (2013), strategies responding to internationalisation have largely overlooked the role of foreign language education in preparing graduates for engaging with and in this globalised world (see also, Bergan \& van't Land, 2010; Byram, 2011; Dlaska, 2012; Klee, 2009; Warner, 2011). This, among other historical factors, have resulted in increasingly low levels of enrolments in modern/foreign languages programs, a condition which, as noted by Brown and Caruso (in press) has been described in terms of 'crisis' or even 'permanent crisis' (Martín, 2005) at universities across the globe (see also Graham \& Santos, 2015).

The precarious situation that modern/foreign languages finds itself in is clearly reflected in numerous reports and scholarly publications at national level particularly in the United States (AACU \& National Leadership Council, 2007; CIGE, 2012; Modern Language Association, 2007), the United Kingdom (Coleman, 2011; Worton, 2009) and Australia (cf. Dunne \& Pavlyshyn, 2012; Nettelbeck et al., 2007; Pauwels, 2007; White \& Baldauf, 2006). These reports and publications paint a paradoxical picture: a firmer focus on internationalisation of $\mathrm{HE}$ against reduced offering of foreign language education.

The vulnerable situation that the field of modern/foreign languages finds itself in means that language teachers - perhaps like colleagues in other Humanities-related disciplines - have to continually justify their existence and relevance in the face of imminent budget cuts that may ultimately result in the termination of their programs. As discussed in earlier paragraphs, institutions have largely resorted to addressing financial constraints by increasing the pressure on language teachers to 'optimise' the delivery of their programs through the integration of 'technology'. In practice, this has largely translated into an increased number of students in the classroom, the reduction of contact hours, and - at risk of generalising - many language teachers in survival mode haphazardly designing and implementing technology-driven curriculum changes which, as discussed earlier, do not lead to true pedagogical innovation. These challenging top-down forces are, in turn, met by two bottom-up challenges.

New learner profile 
The new generation of students entering our classrooms (those born between 1982-2002) has received many labels: Generation Y, Millennial, Generation Me, Boomerang Generation, or 'Digital Natives' (Prensky, 2001a, 2001b, 2010, 2012). However, despite these many labels, the typical profile of these learners can be narrowed down to a number of few key features: confident, selfexpressive, liberal, upbeat and receptive to new ideas and ways of living (Taylor \& Keeter, 2010). In addition, 'digital natives' are considered to "have a natural affinity with technology and, seemingly, are able to effortlessly adopt and adapt to changes in the digital landscape" (Waycott, Bennett, Kennedy, Dalgarno, \& Gray, 2010, p. 1202). An extension of this view includes characteristics such as: being absorbed by all things digital (technology is assumed to be part of their environment), possessing a limited attention span (for a detailed list of these attributes see Frand, 2000; Oblinger, 2003), all of which supposedly makes teaching and motivating them within 'traditional' teaching paradigms quite challenging, to say the least.

Yet, numerous publications and studies conducted over the last few years (Bennett \& Maton, 2010; Bennett, Maton, \& Kervin, 2008; C. Brown \& Czerniewicz, 2010; Helsper \& Eynon, 2010; Jones, Ramanau, Cross, \& Healing, 2010; Kennedy, Judd, Churchward, Gray, \& Krause, 2008; Thomas, 2011; Waycott et al., 2010) challenge this notion and the binary oppositions they create - e.g., 'digital native' versus 'digital immigrants' (cf. Johnson, 2015) - and suggest that a more nuanced approach is needed to define the complexities of the generational differences in the technological skills and experiences of university students and their teachers. Thus, making decisions based on the assumption that our learners - despite coming from such a wide variety of backgrounds - are all experts at or even highly motivated by the use of ICTs may ultimately prove counterproductive.

Nevertheless, we must acknowledge that our practices are also affected by learners' new expectations. In this context, we must endeavour to re-think our face-to-face teaching practices while maintaining the methodological principles underpinning our language teaching approach and seek to foster a much deeper and meaningful language learning experience.

Widening methodological gap

As foreshadowed in earlier paragraphs and as neatly summarised by Dooly (2015, p. 13) "[r]ecent studies show that it is not yet possible to claim that technology has been fully integrated into language teaching, despite the many advances made thus far". Indeed, despite all that has been written about the 
use of ICTs, (language) teachers know little about how they should design activities and tasks for complex learning environments encompassing both synchronous and asynchronous use of technologies, both face-to-face and online components. This may be the result of a number of factors: from the personal lack of interest or willingness to engage in curriculum innovation through ICTs (cf. Sarah K Howard, 2013; Sarah Katherine Howard \& Mozejko, 2015; Johnson, 2015 for a discussion on these ideas) to, most likely, the increasing real time constraints in which they operate as they juggle their teaching and the pressure to publish. This means that the overall innovation and improvement of their courses becomes a relatively low-ranking priority for most language educators. In this context, even when teachers engage in innovation, as highlighted by Laurillard et al., it "often means they simply replicate their current practice in a digital medium" (Laurillard et al., 2013).

Spain presents a clear example of this trend. The conclusions of the preliminary report of the TICSE 2.0 project (TICSE, 2011) 3 state that "traditional teaching materials and resources (such as textbooks and conventional blackboards) remain the methods many of the so-called 'schools 2.0' apply in the classrooms, despite the abundance of digital technology". This can be clearly observed in relation to "learning content" in universities' Learning Management Systems (LMS) platforms (such as Blackboard or Moodle), which seems to have resulted in the mere "digitisation of content", i.e., a digital adaptation of a teaching unit of the textbook we have always used. Moreover, another striking element that adds to the findings of the TICSE report is that teachers have said that the most frequent activities developed with ICTs for the classroom could be framed within a "traditional" educational model (TICSE, 2011, p. 99, quoted by Adell \& Castañeda, 2012, p. 14).

Indeed, as discussed in earlier paragraphs, emerging discourses surrounding the broader context of "technology-enhanced learning" question the focus on technology-led innovation rather than pedagogy-led innovation (cf. Bayne, 2014; Kirkwood \& Price, 2013, 2014). The ability of ICT to transform teaching and improve learning mainly depends on the contexts of use and, within these contexts, our teaching aims. As already noted by Cuban (2001, p. 134):

3 TICSE 2.0 refers to the report on the project “Las políticas de 'un ordenador por niño' en España. Visiones y prácticas del profesorado ante el programa Escuela 2.0. Un análisis comparado entre comunidades autónomas (EDU210-17037)". 
[W]e found [in a survey carried out among high schools and universities] no clear and substantial evidence of students increasing their academic achievement as a result of using information technologies. (...)The overwhelming majority of teachers employed the technology to sustain existing patterns of teaching rather than to innovate. (...) Only a tiny percentage of high school and university teachers used the new technologies to accelerate student centred and project-based teaching practices.

Although we may argue that these findings were expected fifteen years ago when computers were establishing their presence in our classrooms, academic achievements reached in the recent Programme for International Student Assessment (Pisa) tests seems to confirm Cuban's concerns. The latest survey, taken in 2012, demonstrates that students from countries that score higher in the PISA tests spend less time in school using computers than their European and American counterparts.

As the final report (OECD 2015 p. 15) explains, PISA results show - among other things - three important findings. Firstly, student achievement in reading, mathematics or science show no evidence of substantial improvements in the countries that have greatly invested in ICT for education. Secondly, better student performance can be linked to ICT only in certain contexts (for instance, when emerging technologies help increase study time and practice). Finally, a limited exposure to computers at school may be better than not using computers at all. In fact, a more intensive use than the current OECD average could be associated with poorer student-performance.

The results still confirm Cuban's view expressed at the turn of this century: emerging ICTs (identified nowadays with computers, tablets, smart blackboards and mobile telephony) have not succeeded in promoting a student-centred approach to instruction (2001). Rather, they still support a teacher-centered approach, where teaching practitioners do in a new format what they have been doing traditionally with books, photocopies, overhead transparencies and conventional blackboards. Therefore, although new technologies have found a place in our classrooms, their effects have not been as influential as originally thought. In effect, new devices and the software that comes with them have reinforced not altered our so-called traditional teaching approaches. Finally, as highlighted by Kirkwood and Price (2013, p. 335) "even if pedagogic issues are considered first, the adoption of technology might make little difference to student outcomes if teaching is not reconceptualised in relation to TEL." 


\section{Pedagogic intervention: Bridging the methodological gap}

Despite the considerably pessimistic perspective that emerges from our critical consideration of key challenges, we remain hopeful regarding the possibilities that ICTs can offer. And part of being critical about our articulation of these issues, also requires us to acknowledge that much of this macro-level critique still lacks micro-level curricular applications once we cross the threshold of the classroom door. This is indeed the fulcrum point of the methodological gap. In this section we present our own pedagogical response to these challenges. We do not consider nor argue that this is an allencompassing, definitive solution, in fact, we do not believe there is one. On the contrary, we simply present this as a modest response, which is, above all, pedagogically situated in the context of our everyday practice and ultimately seeks to 'mediate' (Clegg et al., 2003) between top-down institutional targets and our own bottom-up, pedagogically-driven agendas (cf. Lobato, Gargallo, \& Casado, 2004).

Our intermediate Spanish language courses (equivalent to the B1 proficiency level in the CEFR) are part of a university program established approximately twenty years ago. Students in these courses have a mixed linguistic profile, some of them have studied from beginner levels with us; others join these courses after achieving intermediate proficiency level in high school or through overseas travel and/or study experiences. As a result, their ages and language learning experiences are also quite varied. The classes generally comprise twenty-five to thirty students. While the courses are delivered by one teacher, the curriculum is designed by a team of two teachers.

The courses comprise four weekly contact hours over a thirteen-week academic semester. Faced with the pressure to maximise the use of this precious time with our students and with a view to the imminent reduction of contact time, our ongoing curricular innovation has consisted in re-thinking our face-to-face teaching practices to foster a much deeper and meaningful language learning experience. Indeed, as discussed the previous section, while much of the technology-driven responses have focused on the development of instructional materials designed for online learning, in many ways, this overemphasis has neglected the use of technology for student engagement in complementary face-to-face teaching modes. Thus, our curriculum intervention stemmed from the need to address this equally relevant imperative. This pedagogically-driven intervention was developed gradually and progressively over several semesters with many Action Research cycles of planning, implementation and evaluation. 
We focused on the use of the freely available and widely used PowerPoint ${ }^{\circledR}$ software, already a staple component of our face-to-face teaching, as a medium through which to engage our highly visually-literate generation of students both inside and outside the classroom. The main underlying rationale for our curriculum intervention was to revamp our courses by "capsizing the traditional hierarchy of text to image" (Pacansky-Brock, 2013, p. 9), sound and movement with visually-centric, highly engaging, interactive materials and activities that may complement their textbook material and ultimately, promote deep-learning. The formal integration of this material into our courses was thus rationalised in relation to four specific instructional axes: 1) present, 2) explain, 3) practice, and 4) assess (in Spanish - 4xE: exponer, explicar, ejercitar and evaluar). The following paragraphs describe our approach for the development of PowerPoint ${ }^{\circledR}$-based materials under each of these instructional functions.

Before delving into our development of PowerPoint $\AA$ presentations (henceforth PPTs), it is important to mention that, as part of their "digital resources package", several publishing houses already supply language teachers with pre-packaged PPTs, provided to facilitate the presentation of inclass material. However, in general, these presentations largely replicate images, text and explanations from the textbook pages (see examples from Wiley but also McGraw Hill, Cengage Learning and Difusión), and, as such they tend to be highly static, and have very limited use of differentiated text and meaningful use of animations. Of course, this allows individual teachers to customise them by adding their own animations and generally apply changes as they see fit. Yet, in most cases it is the lack of interactivity in these presentations that made us reconsider their use in our classes. Here, it is also important to note that lecture-like content classes at university have, for some time, relied heavily on the use of PPTs and their application has been studied from many angles (cf. Craig \& Amernic, 2006; Levasseur \& Kanan Sawyer, 2006). However, little is known about their impact within the specific context of language instruction (cf. Corbeil, 2007; Hawkes, 2009; Oommen, 2012).

Presenting linguistic input

In order to engage the new learner profile described above, we needed more than the typically available static images and tables with language input. However, it was also important to distance ourselves from the typical "bells and whistles" approach to PPT slides, which had long been mistaken for best practice. Instead, we resorted to a visually-centric approach to content creation guided by the neurological principle "vision trumps all other senses" 
(Medina, 2010) and emerging research in the field of Spanish as a foreign/second language (cf. Foncubierta, 2013a, 2013b; Foncubierta, 2013c; Goldstein, 2012). This approach entailed the use of various types of visual and aural presentations of language, from the traditional use of comics and famous works of art, to new types of visual representations such as memes and infographics (both static and animated) (Berk, 2011, 2012). These were particularly useful to introduce new topics, vocabulary as well as to discuss intercultural and political aspects to new student cohorts with increasing levels of visual literacy (i.e., the ability to create, decode, use and interpret the meaning(s) behind a variety of visual text). See for example Figure 1 below, an image that helped us to a) revise basic vocabulary to refer to colours, b) introduce more sophisticated ways of describing different shades of colours and, c) at the same time raising learners' critical awareness of language and gender stereotypes.

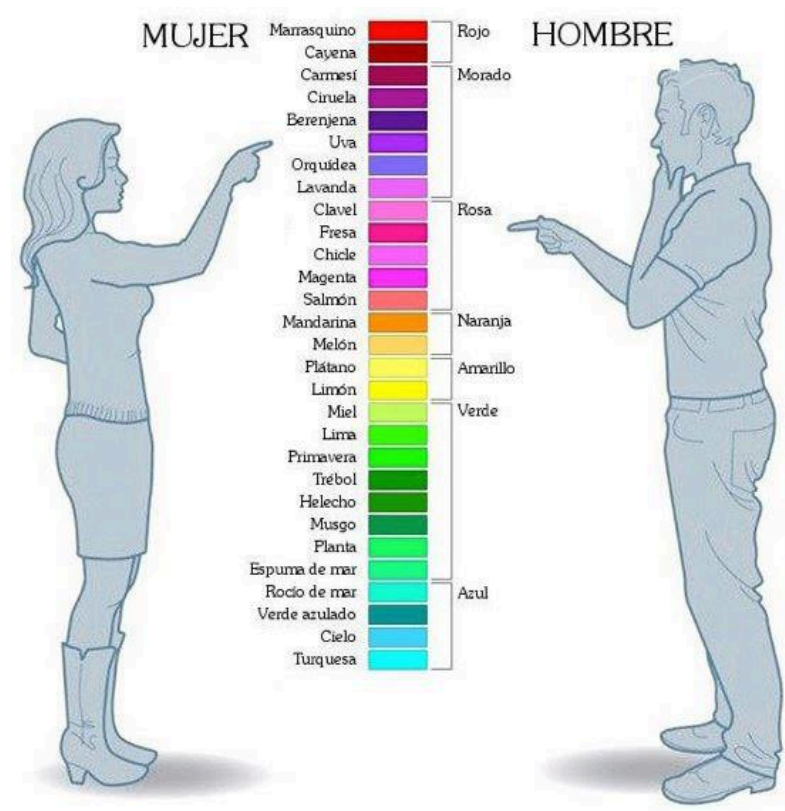

Figure 1 - Men vs. Women naming colours (image source: http://www.almudenagancedo.es/dantone-colores/).

These types of image formats, memes and infographics in particular, mirror the type of visual information students are being exposed to through social media channels, thus making them particularly appealing in the classroom. The creation of visually-centric resources was substantiated by established 
psychological principles such as the picture superiority effect (Nelson, Reed, \& Walling, 1976; Paivio, Rogers, \& Smythe, 1968), according to which, when we are exposed to input that is both visual and spoken, we will remember $65 \%$ of what has been said/shown to us, that is, over six times as much as just spoken input.

\section{Explaining grammar}

When designing explanations, in particular, grammatical explanations, we also had to re-envision our pedagogical approach, which had thus far favoured an implicit teaching of grammar. We opted for an explicit focus on form through visual explanations in our PPTs. Here, it is important to note that a number of relevant studies have indicated that, while there are no significant advantages over traditional textbook explanations, learners value the engaging nature of information presented in PPTs rather than paper-based textbook (Corbeil, 2007). Indeed, according to Corbeil "colour coding, bolding, font manipulation, underlining, animation schemes, and custom animation all serve to make grammatical rules more salient" (2007, p. 632).

These explanations and corresponding slide design were additionally imbued with the use of cognitive psychology principles to promote meaningful learning (Kosslyn, 2007). These eight principles are grouped under three main goals in PPT design (see Table 1, below).

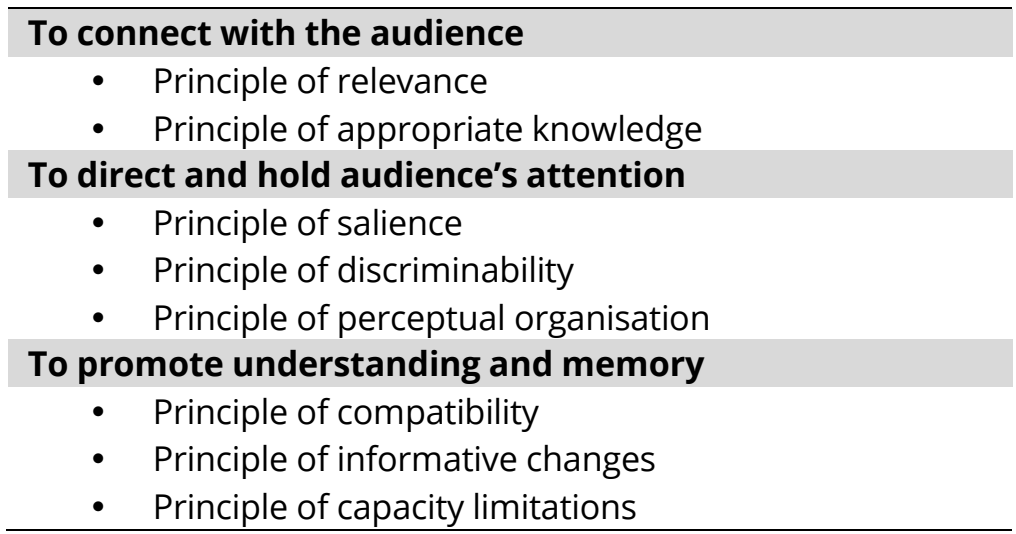

Table 1. Kosslyn's psychological principles for compelling PPTs.

Finally, in addition to the use of these principles to enhance students' noticing of grammatical patterns, we also resorted to the complementary use of cognitive grammar (CG) principles developed in the context of Spanish as a foreign/second language (cf. Llopis-García, 2011; Llopis-García, Real Espinosa, 
\& Ruiz Campillo, 2012; Llopis García, 2011; López García, 2004). The rationale behind this deliberate choice to use a CG approach was its compatibility with a visual exploration of the complex, dynamic and multidimensional nature of meaning behind speakers' grammatical choices. That is, CG principles emphasise the relationship between lexical and grammatical meaning as well as the metonymic and metaphorical aspects of grammatical rules (cf. Alhmoud \& Castañeda Castro, 2015), these are all abstract concepts that can be rendered visually concrete through the affordances of PPT. In other words, the use of PPTs within these theoretical frameworks allowed us to make our explanations come to life through the combination of text, images and strategic use of animation.

In Figure 2 below we can see two slides representing the contrast between the use of the preposition IN in English - visually represented through the 'container image-schema' (Langacker, 1987) - and the use of the preposition POR in Spanish - represented as temporal space being traversed (see Hortiguera, 2015; Hortiguera \& Díaz, 2014, for additional examples on the pedagogical translation of these principles).
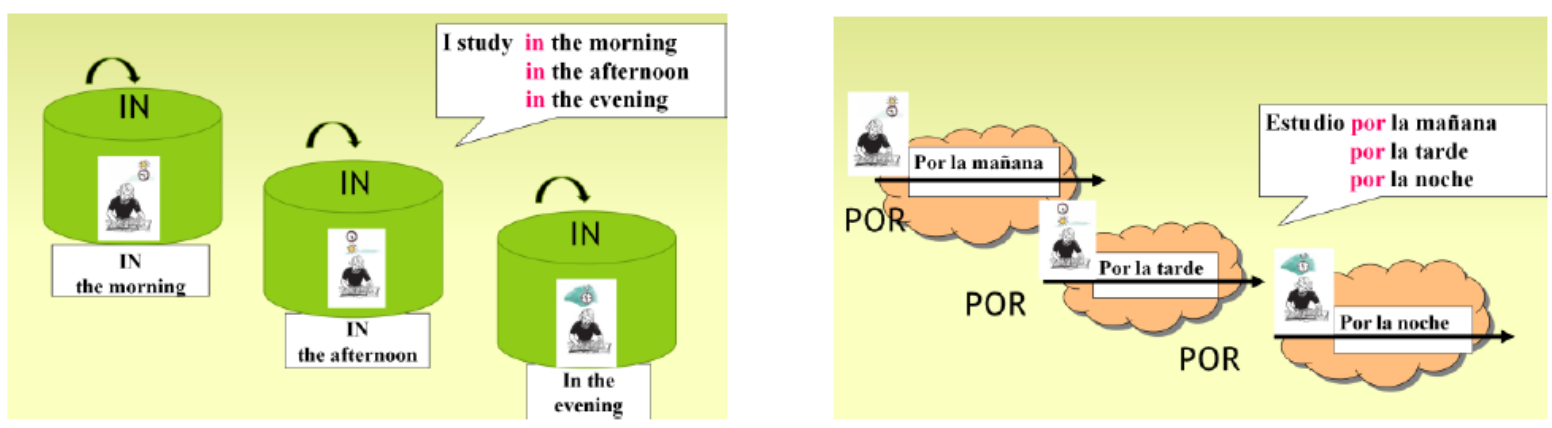

Figure 2. Contrast between prepositions IN \& POR.

\section{Practising}

In developing exercises with PPTs, the key aspect we endeavoured to address was interactivity. In each lesson, practical exercises were organised from the more teacher-guided to free students' production. For instance, following the grammatical explanation of a new tense, the typical pedagogic sequence of activities consisted in:

- Traditional fill in the blank activities (colour-coded infinitive form of the verbs provided) supported with visual information. 
- Traditional fill in the blank activities supported with visual information (no verbs provided).

- Slides with visual information for students to produce target forms.

These activities were implemented in a variety of ways, ranging from teachercentred activities to pair-work and individual work on printed versions of the slides. In addition to this type of practice activities, we also incorporated instructional games such Memory Games, Who wants to be a millionaire?, etc. for in-class revision and exam practice. The use of instructional games was substantiated by recent studies (Siko, Barbour, \& Toker, 2011; Siko \& Barbour, 2012). These games also allowed for the incorporation of collaborative group work.

\section{Assessing}

In terms of assessment, we requested students to create their own PPTs for the courses' oral assessment. Students were required to record their 'stories', real or imagined, while incorporating all the vocabulary and grammatical structures learned thus far in the course. Students were asked to submit their PPTs through an online platform (using freely available applications such as Knovio or VoiceThread). The underlining rationale for this piece of assessment consisted in mirroring the type of visually-centric presentation of the language we provided in class, pairing visual stimuli with storytelling techniques. These tasks aimed to engage learners in the personalised creation of short narratives in the target language based on the selection of their own images thus also enhancing the affective engagement (Arnold, 2000) with the task at hand.

\section{Discussion: Outcomes of intervention - Challenges and possibilities}

Overall, since we started the development of our PPTs, students' course evaluations have provided largely positive feedback on various aspects of their implementation and thus, confirmation that our pedagogical goal is gradually being met. However, we also encountered a number of practical challenges along the way. Interestingly, and despite claims regarding the advent of a digital learning era in education discussed in earlier sections of this paper, we encountered some resistance, and at times, reluctance, from learners as well as teachers, to the development and integration of PPTs in our teaching. Some students, both mature age and school-leavers, found it hard to prepare their own PPTs for their oral assessment. After several iterations of these courses, we found that providing students with detailed instructions on how to use 
technology (PPTs and the online platforms) was not enough. Students also needed to know the reasons behind the use of the technology, why was using this technology in their oral assessment an important aspect of their language learning experience.

The structure and features of each module/task (i.e., technical features, such as the animations, buttons; the use of target language or L1 in instructions; the online feedback and how to use).

The type of sequencing of face-to-face and online learning tasks, whether it is:

- a linear one: i.e., students access and work through the relevant online activities before or after face-to-face classwork; or

- a spiral, iterative one: i.e. the students come back to the online modules for revision, consolidation of concepts, content and learning strategies whenever they feel the need to do so. They use of online tasks as a learning aid to get a better understanding of new content and concepts presented in class.

This is an aspect that we are still exploring in order to better support our students' achievements.

Informal interviews with the small team of casual teachers involved revealed that, at times, they struggled with having to complement so-called 'traditional' approaches to language teaching with the PPT slides we prepared. Indeed, we realised that in order to develop visually- centric PPT slides, our overall pedagogical approach to teaching had to change. This implied helping our team of teachers' rethink their teaching philosophy in light of the affordances provided by PPTs, but also, developing their 'digital competence'. The latter is another aspect that we would like to explore in future iterations of our courses.

Another interesting outcome yielded by this pedagogic intervention was the positive effect PPTs had on our lesson-planning strategies, from the organisation of the content to the use of the Notes function to explain the reasoning behind certain activities and to provide instructions on how to exploit the images provided. This effect of PPTs, which has been largely unexplored (Hawkes, 2009), presented several advantages for us and the teaching team involved. On the one hand, it allowed us to consider the students' learning process at all times. On the other hand, it also allowed us to share our insights into this process in a team-teaching environment, to share teaching ideas and resources (Hashemi, Azizinezhad, \& Farokhi, 2012). This meant, for instance, that we could also provide instructional scaffolding to our less-experienced tutors. In addition, as highlighted by Hawkes, it made the teaching process "less stressful, more effortless" as we relied on the pre- 
planned "pace, transitions" (2009, p. 87) and pre-developed sequences of learning activities. In the long-term, this type of planning has also proved timeefficient for recycling, updating and adapting PPTs in subsequent lessons and iterations of these courses. These features of the use of PowerPoint ${ }^{\circledR}$ may seem apparent but not usually valued. In the current context of $H E$, the reduction of time dedicated to teaching, increased multi-campus lessondelivery, reductions of contact hours, and pressures on increased volume of research outputs, they have certainly proved useful.

\section{Conclusion}

In this paper we have articulated key challenges involved in the pedagogicallydriven integration of ICTs in today's university language classrooms. We did so from the non-specialist/non-expert teacher/practitioner's perspective. We believe that the articulation of these challenges is essential to the development of a critical stance that may lead to the empowerment of language educators working in the HE sector across the globe.

We complemented our critique with practical examples of pedagogical strategies implemented to meet these challenges in our own situated Spanish language teaching context. Far from making any claims of 'disruptive innovation' our pedagogical strategies present as a modest example of how our engagement with ICTs helped us integrate and address specific concerns within the context of our own classrooms. And while we made no claims regarding generalisability, we endeavoured to frame the discussion of these strategies in a way that may be easily transposable to comparable language learning contexts. In so doing, we highlighted our use of freely available programs and applications that helped us re-think students' engagement with the content both inside and outside the classroom. In turn, re-thinking the delivery of content served as a catalyst to reconceptualise our overall approach to language teaching (specifically in relation to visual literacy and grammar). Our integration of 'technology' was thus a means to an end rather than the end in itself.

In a recent publication, Dooly highlights that "[j]ust as future professions are predicted to change dramatically, it is proposed that how we teach and learn may be unrecognizable in less than fifty years' time" and in this context, "as language -or communication - teachers, our role in this evolution is paramount" (2015, p. 22). We echo Dooly's words and contend that as key actors in this complex, fast-changing educational landscape, we need to maintain a critical stance fundamentally grounded in pedagogical principles. 
Taking this into account, we need to ensure that both pre-service and inservice teachers engage in this reflective practice, remaining critical of the various discourses, assumptions and complexities surrounding the use of technology.

\section{About the authors}

Dr. Adriana Raquel Díaz is Lecturer at the School of Languages and Cultures, University of Queensland, Australia. Her main research activities focus on the development of intercultural competence, the variables affecting the implementation of intercultural language curricula and teaching methodologies as well as teachers' journeys in the development of intercultural language learning pedagogies. She is the author of Developing Critical Languaculture Pedagogies in Higher Education: Theory and Practice (2013, Bristol: Multilingual Matters).

Dr. Hugo Hortiguera is Senior Lecturer in Spanish at Griffith University (Australia). He specializes in contemporary Argentine literature and media. $\mathrm{He}$ is the author of Argentinean Cultural Production During the Neoliberal Years (1989-2001) (in coll. with Dr. Carolina Rocha, 2007) and La literatura cambalachesca en la novelística de Osvaldo Soriano (2007). His articles have been published in Ciberletras. Journal of Literary Criticism and Culture, Studies in Latin American Popular Culture, Estudios sobre el mensaje periodístico, and in Delaware Review of Latin American Studies.

\section{Article history}

Paper received: $07^{\text {th }}$ February 2016

Paper received in revised form and accepted for publication: $04^{\text {th }}$ April 2016

\section{References}

AACU, \& National Leadership Council. (2007). College learning for the new global century: A report from the National Leadership Council for liberal education \& America's promise. Washington, D.C.: Association of American Colleges and Universities. 
Adell, J., \& Castañeda, L. (2012). Tecnologías emergentes, ¿pedagogías emergentes? In J. Hernández Ortega, M. Pennesi Fruscio, D. Sobrino López \& A. Vázquez Gutiérrez (Eds.), Tendencias emergentes en educación con TIC (pp. 13-32). Barcelona: Espiral.

Alhmoud, Z., \& Castañeda Castro, A. (2015). Más de gramática, más que gramática. De lingüística cognitiva y enseñanza de ELE. Doblele - Español Lengua Extranjera - Revista de Lengua y Literatura, 1(diciembre), 101-135.

Arnold, J. (2000). La dimensión afectiva en el aprendizaje de idiomas. Cambridge: Cambridge University Press.

Bayne, S. (2014). What's the matter with 'technology-enhanced learning'? Learning, Media and Technology, 40(1), 5-20. doi:10.1080/17439884.2014.915851

Bennett, S., \& Maton, K. (2010). Beyond the 'digital natives' debate: Towards a more nuanced understanding of students' technology experiences. Journal of Computer Assisted Learning, 26(5), 321-331.

Bennett, S., Maton, K., \& Kervin, L. (2008). The 'digital natives' debate: A critical review of the evidence. British Journal of Educational Technology, 39(5), 775-786.

Bergan, S., \& van't Land, H. (2010). Speaking across borders: The role of higher education in furthering intercultural dialogue. Strasbourg: Council of Europe.

Berk, R. A. (2011). "Powerpoint ${ }^{\circledR}$ Engagement" Techniques to foster deep learning. The Journal of Faculty Development, 25(2), 45-48. Retrieved from http://newforums.metapress.com/ content/ X153H86386828071

Berk, R. A. (2012). Top 10 evidence-based, best practices for PowerPoint $\AA$ in the classroom. Transformative Dialogues: Teaching \& Learning eJournal, 5(3), 1-7.

Bernstein, K. A., Hellmich, E. A., Katznelson, N., Shin, J., \& Vinall, K. (2015). Introduction to special issue: Critical perspectives on Neoliberalism in second/foreign language education. $L 2$ Journal, 7(3), 3-14.

Blake, R. J. (1998). The role of technology in second language learning. In H. Byrnes (Ed.), Learning foreign and second languages: Perspectives in research and scholarship (Vol. 2, pp. 209-237). New York: Modern Language Association.

Blake, R. J. (2000). Computer mediated communication: A window on L2 Spanish interlanguage. Language Learning \& Technology, 4(1), 120-136.

Blake, R. J. (2001). What language professionals need to know about technology. ADFL Bulletin, 32(3), 93-99.

Blake, R. J. (2006). Two heads better than one: Computer mediated communication for the $L 2$ curriculum. In R. Donaldson \& M. A. Haggstrom (Eds.), Changing language education through CALL (pp. 229-248). London: Routledge.

Blake, R. J. (2007). New trends in using technology in the language curriculum. Annual Review of Applied Linguistics, 27, 76-97.

Blake, R. J. (2008). Brave new digital classroom: Technology and foreign language learning. 
Washington, DC: Georgetown University Press.

Blake, R. J. (2010). Best practices in online learning: Is it for everyone? In F. Rubio \& J. J. Thoms (Eds.), Hybrid language teaching and learning: Exploring theoretical, pedagogical and curricular issues (pp. 10-26). Boston: Cengage/Heinle.

Bowen, W. G., \& Lack, K. A. (2012). Current status of research on online learning in postsecondary education. Retrieved from http://continuingstudies.wisc.edu/innovation/ithaka-sr-onlinelearning.pdf

Brown, C., \& Czerniewicz, L. (2010). Debunking the 'digital native': beyond digital apartheid, towards digital democracy. Journal of Computer Assisted Learning, 26(5), 357-369.

Brown, J., \& Caruso, M. (in press). Access Granted: Modern Languages and Issues of Accessibility at University. A case study from Australia. Language Learning in Higher Education, 6(2).

Bulfin, S., Johnson, N. F., \& Bigum, C. (2015). Critical perspectives on technology and education. New York: Palgrave Macmillan.

Byram, M. (2011). A note on internationalisation, internationalism and language teaching and learning. The Language Learning Journal, Vol 40(3), 1-7. doi:10.1080/09571736.2011.642528

CIGE. (2012). Mapping internationalization on U.S. campuses: 2012 Edition. Retrieved from One Dupont Circle NW, Washington, DC: http://www.acenet.edu/links/pdfs/cige/Mapping InternationalizationonUSCampuses2012-full.pdf

Clegg, S., Hudson, A., \& Steel, J. (2003). The emperor's new clothes: Globalisation and e-learning in higher education. British journal of sociology of education, 24(1), 39-53.

Coleman, J. A. (2011). Modern Languages in the United Kingdom. Arts and Humanities in Higher Education, 10(2), 127-129. doi:10.1177/1474022211401860

Corbeil, G. (2007). Can PowerPoint presentations effectively replace textbooks and blackboards for teaching grammar? Do students find them an effective learning tool? CALICO Journal, 24(3), 631-656.

Craig, R., \& Amernic, J. (2006). PowerPoint presentation technology and the dynamics of teaching. Innovative Higher Education, 31(3), 147-160. doi: 10.1007/s10755-006-9017-5

Cubillos, J. H. (2014). Spanish textbooks in the US: enduring traditions and emerging trends. Journal of Spanish Language Teaching, 1(2), 205-225. doi: 10.1080/23247797.2014.970363

Díaz, A. R. (2013). Developing critical languaculture pedagogies in higher education: Theory and practice. Bristol: Multilingual Matters.

Dlaska, A. (2012). The role of foreign language programmes in internationalising learning and teaching in higher education. Teaching in Higher Education, 1-12. doi: 10.1080/13562517.2012.696538

Dooly, M. (2015). Learning to e-function in a brave new world: Language teachers' roles in educating for the future. In A. Turula, B. Mikołajewska \& D. Stanulewicz (Eds.), Insights into technology enhanced language pedagogy (pp. 11-25). Bern/Vienna: Peter Lang. 
Dooly, M., \& Masats, D. (2015). A critical appraisal of foreign language research in content and language integrated learning, young language learners, and technology-enhanced language learning published in Spain (2003-2012). Language Teaching, 48(03), 343-372. doi: $10.1017 / S 0261444815000117$

Dunne, K. S., \& Pavlyshyn, M. (2012). Swings and roundabouts: changes in language offerings at Australian universities 2005-2011. In J. Hajek, C. Nettelbeck \& A. Woods (Eds.), The next step: Introducing the languages and cultures network for Australian universities: Selected proceedings of LCNAU's inaugural colloquium in 2011 (pp. 9-19). Melbourne: LCNAU.

Fevolden, A. M., \& Tømte, C. E. (2015). How information and communication technology is shaping higher education. In J. Huisman, H. de Boer, D. D. Dill \& M. Souto-Otero (Eds.), The Palgrave international handbook of higher education policy and governance (pp. 342-358). New York, NY: Palgrave Macmillan.

Foncubierta, J. M. (2013a). Alfabetización visual, uso de imágenes y recursos para la enseñanza - Estocolmo, Junio 2013 - Editorial Edinumen. Retrieved from http://www.encuentroestocolmo.com/wp-content/uploads/2013/08/Curso-de-formación-para-profesores-deespañol.pdf

Foncubierta, J. M. (2013b). Imágenes mentales y visualización: Ejercicios para el desarrollo de algunas estrategias. Revista Nebrija de Lingüística Aplicada - No. 13 (Número Especial - Actas de Congreso). Retrieved from http://www.nebrija.com/revista-linguistica/revistalinguistica-nebrija13/htm/Foncubierta.htm

Foncubierta, J. M. (2013c). Técnicas de visualización para la comprensión y producción de textos orales o escritos - III Congreso ELE Global, 26 de Junio de 2013.

Frand, J. L. (2000). The information-age mindset changes in students and implications for higher education. Educause Review, 35, 14-25. Retrieved from http://www.educause.edu/ ir/library/pdf/ERM0051.pdf

Gimeno-Sanz, A. (2015). Moving a step further from "integrative CALL". What's to come? Computer Assisted Language Learning, 1-16. doi:10.1080/09588221.2015.1103271

Giroux, H. A., \& Myrsiades, K. (2001). Beyond the corporate university: Culture and pedagogy in the new millennium. Oxford, UK: Rowman \& Littlefield.

Goldstein, B. (2012). El poder de la imagen: El uso de las imágenes en la clase de ELE. MOSAICO, 29(Junio), 19-23.

Golonka, E. M., Bowles, A. R., Frank, V. M., Richardson, D. L., \& Freynik, S. (2012). Technologies for foreign language learning: A review of technology types and their effectiveness. Computer Assisted Language Learning, 27(1), 70-105. doi:10.1080/09588221.2012.700315

González, P. D. J. (2012). Uso de las nuevas tecnologías en la enseñanza de lenguas extranjeras. Revista de Lenguas para Fines Específicos, 18, 183-212.

Graham, S., \& Santos, D. (2015). Language learning in the public eye: an analysis of newspapers and official documents in England. Innovation in Language Learning and Teaching, 9(1), 72 85. doi:10.1080/17501229.2014.995766 
Hashemi, M., Azizinezhad, M., \& Farokhi, M. (2012). Power Point as an innovative tool for teaching and learning in modern classes. Procedia - Social and Behavioral Sciences, 31, 559563. doi:10.1016/j.sbspro.2011.12.103

Hawkes, R. (2009). Digital technology as a tool for active learning in MFL: Engaging language learners in and beyond the secondary classroom. In M. Evans (Ed.), Foreign language learning with digital technology (pp. 80-103). London; New York: Continuum.

Helsper, E. J., \& Eynon, R. (2010). Digital natives: Where is the evidence? British Educational Research Journal, 36(3), 503-520.

Henderson, M., \& Romeo, G. (Eds.). (2015). Teaching and digital technologies: Big issues and critical questions. Melbourne, VIC: Cambridge University Press.

Hortiguera, H. (2015). Diseños de aprendizaje y espacios de interacción en la enseñanza de ELE". Revista RedELE, 27. Retrieved from http://www.mecd.gob.es/dctm/redele/MaterialRedEle/Revista/201527/2015redele2715hugohortiguera2.pdf?documentld=0901e72b81f Odcb9

Hortiguera, H., \& Díaz, A. (2014). Extendiendo los muros de la clase de ELE: una aproximación (neuro) cognitiva a través de la tecnología. MarcoElE: Revista de didáctica, 19(JulyDecember).

Howard, S. K. (2013). Risk-aversion: Understanding teachers' resistance to technology integration. Technology, Pedagogy and Education, 22(3), 357-372.

Howard, S. K., \& Mozejko, A. (2015). Teachers: Technology, change and resistance. In M. Henderson \& G. Romeo (Eds.), Teaching and digital technologies: Big issues and critical questions (pp. 307-317). Melbourne, VIC: Cambridge University Press.

Johnson, N. F. (2015). Digital natives and other myths. In M. Henderson \& G. Romeo (Eds.), Teaching and digital technologies: Big issues and critical questions (pp. 11-21). Melbourne, VIC: Cambridge University Press.

Jones, C., Ramanau, R., Cross, S., \& Healing, G. (2010). Net generation or digital natives: Is there a distinct new generation entering university? Computers \& Education, 54(3), 722-732.

Kennedy, G. E., Judd, T. S., Churchward, A., Gray, K., \& Krause, K.-L. (2008). First year students' experiences with technology: Are they really digital natives. Australasian Journal of Educational Technology, 24(1), 108-122.

Kirkwood, A., \& Price, L. (2013). Missing: evidence of a scholarly approach to teaching and learning with technology in higher education. Teaching in Higher Education, 18(3), 327-337. doi:10.1080/13562517.2013.773419

Kirkwood, A., \& Price, L. (2014). Technology-enhanced learning and teaching in higher education: what is 'enhanced' and how do we know? A critical literature review. Learning, Media and Technology, 39(1), 6-36. doi: 10.1080/17439884.2013.770404

Klee, C. A. (2009). Internationalization and foreign languages: The resurgence of interest in languages across the curriculum. The Modern Language Journal, 93(4), 618-621. doi: 10.1111/j.1540-4781.2009.00936.x 
Kosslyn, S. M. (2007). Clear and to the point: 8 Psychological principles for compelling PowerPoint presentations. New York: Oxford University Press.

Langacker, R. (1987). Foundations of cognitive grammar: Theoretical prerequisites (Vol. 1). Stanford: Stanford university press.

Laurillard, D., Charlton, P., Craft, B., Dimakopoulos, D., Ljubojevic, D., Magoulas, G., Whittlestone, K. (2013). A constructionist learning environment for teachers to model learning designs. Journal of Computer Assisted Learning, 29(1), 15-30. doi: 10.1111/j.13652729.2011.00458.x

Levasseur, D. G., \& Kanan Sawyer, J. (2006). Pedagogy meets PowerPoint: A research review of the effects of computer-generated slides in the classroom. Review of Communication, 6(12), 101-123. doi: 10.1080/15358590600763383

Liu, M., Moore, Z., Graham, L., \& Lee, S. (2002). A look at the research on computer-based technology use in second language learning. Journal of Research on Technology in Education, 34(3), 250-273. doi:10.1080/15391523.2002.10782348

Llopis-García, R. (2011). Cognitive grammar: Marking new paths in foreign language teaching. Verba Hispanica, 19(1), 111-127.

Llopis-García, R., Real Espinosa, J. M., \& Ruiz Campillo, J. P. (2012). Qué gramática enseñar, qué gramática aprender. Madrid: Edinumen.

Llopis-García, R. (2011). Gramática cognitiva para la enseñanza del español como lengua extranjera. Madrid: Ministerio de Educación de España.

Lobato, J. S., Gargallo, I. S., \& Casado, V. L. (2004). Vademécum para la formación de profesores: enseñar español como segunda lengua (L2)/lengua extranjera (LE). Madrid: Sociedad General Española de Librería.

López García, Á. (2004). Gramática cognitiva para profesores de español L2. Madrid: Arco/Libros.

Martín, D. (2005). Permanent crisis, tenuous persistence: Foreign languages in Australian universities. Arts and Humanities in Higher Education, 4(1), 53-75.

Medina, J. (2010). Brain Rules: 12 Principles for surviving and thriving at work, home, and school. Seattle, WA: Pear Press.

Modern Language Association. (2007). Foreign languages and higher education: New structures for a changed world. Retrieved from http://www.mla.org/pdf/forlang_news_pdf.pdf

Nelson, D. L., Reed, V. S., \& Walling, J. R. (1976). Pictorial superiority effect. Journal of Experimental Psychology: Human Learning and Memory, 2(5), 523.

Nettelbeck, C., Byron, J., Clyne, M., Hajek, J., Lo Bianco, J., \& McLaren, A. (2007). Beginners' LOTE (Languages Other than English) in Australian universities: An audit survey and analysis. Retrieved from: http://www.humanities.org.au/Portals/0/documents/Policy/Research/ Languages/txt/BeginnersLOTEAuditLASP1.pdf 
Nettelbeck, C., Hajek, J., \& Woods, A. (2012). Re-professionalizing the profession: countering juniorization and casualization in the tertiary languages sector. Journal of Local-Global Special Issue: Globalization, Languages, Knowledge: Australian languages education in the 'Asian Century', 9, 60-75.

Oblinger, D. (2003). Boomers Gen-Xers Millennials. Educause Review, 500(4), 37-47. Retrieved from http://www.educause.edu/ir/library/pdf/ERM0342.pdf

Oommen, A. (2012). Teaching English as a global language in smart classrooms with PowerPoint presentation. English Language Teaching, 5(12), 54.

Pacansky-Brock, M. (2013). Best practices for teaching with emerging technologies. New York, NY: Routledge.

Paivio, A., Rogers, T. B., \& Smythe, P. C. (1968). Why are pictures easier to recall than words? Psychonomic Science, 11(4), 137-138.

Pauwels, A. (2007). Maintaining a language other than English through higher education in Australia. In A. Pauwles, J. Lo Bianco \& J. Winter (Eds.), Maintaining minority languages in transnational contexts (pp. 107-123). London: Palgrave.

Prensky, M. (2001a). Digital natives, digital immigrants (Part I). Retrieved from http://www.marcprensky.com/writing/prensky\%20-\%20digital\%20natives,\%20digital\%20 immigrants\%20-\%20part1.pdf

Prensky, M. (2001b). Digital natives, do they really think differently? (Part II). http://marcprensky.com/writing/PrenskyDigitalNatives,DigitallmmigrantsPartll.pdf Retrieved from http://marcprensky.com/writing/PrenskyDigitalNatives,Digitallmmigrants Partll.pdf

Prensky, M. (2010). Teaching digital natives: Partnering for real learning. Thousand Oaks, CA: Corwin.

Prensky, M. (2012). From digital natives to digital wisdom: Hopeful essays for 21st Century learning. Thousand Oaks, CA: Corwin.

Román-Mendoza, E. (2014). Tecnología y enseñanza del español en los Estados Unidos: hacia un mayor protagonismo del alumno como gestor de su propio aprendizaje. Journal of Spanish Language Teaching, 1(2), 187-204.

Selwyn, N. (2007). The use of computer technology in university teaching and learning: a critical perspective. Journal of Computer Assisted Learning, 23(2), 83-94. doi: 10.1111/j.13652729.2006.00204.x

Selwyn, N. (2013). Distrusting educational technology: Critical questions for changing times. New York: Routledge.

Selwyn, N. (2015a). Minding our language: why education and technology is full of bullshit ... and what might be done about it. Learning, Media and Technology, 1-7. doi: 10.1080/17439884.2015.1012523

Selwyn, N. (2015b). Technology and education-why it's crucial to be critical. In S. Bulfin, N. F. Johnson \& C. Bigum (Eds.), Critical perspectives on technology and education (pp. 245-255). 
New York, NY: Springer.

Siko, J., Barbour, M., \& Toker, S. (2011). Beyond jeopardy and lectures: Using microsoft powerpoint as a game design tool to teach science. Journal of Computers in Mathematics and Science Teaching, 30(3), 303-320.

Siko, J., \& Barbour, M. K. (2012). Homemade PowerPoint games: Game design pedagogy aligned to the TPACK framework. Computers in the Schools, 29(4), 339-354. doi: 10.1080/07380569.2012.734430

Taylor, P., \& Keeter, S. (2010). Millennials - A portrait of generation next: Confident, connected, open to change. Washington, D.C.: Pew Research Center.

Thomas, M. (2011). Deconstructing digital natives: Young people, technology, and the new literacies. New York; London: Routledge.

Warner, C. (2011). Rethinking the role of language study in internationalizing higher education. L2 Journal, 3(1), 1-21. Retrieved from http://www.escholarship.org/uc/item/7188g4z0

Waycott, J., Bennett, S., Kennedy, G., Dalgarno, B., \& Gray, K. (2010). Digital divides? Student and staff perceptions of information and communication technologies. Computers \& Education, 54(4), 1202-1211.

White, P., \& Baldauf, R. (2006). Re-Examining Australia's Tertiary Language Programmes - A Five Year Retrospective on Teaching and Collaboration. Retrieved from http://altcfellowship.murdoch.edu.au/Docs/whitebauldaufreport2006.pdf

Winner, L. (2013). Technologies as forms of life (1983). In R. L. Sandler (Ed.), Ethics and emerging technologies (pp. 48-60). New York, NY: Palgrave Macmillan.

Worton, M. (2009). Review of modern foreign languages provision in higher education in England. Retrieved from: http://www.hefce.ac.uk/pubs/hefce/2009/09_41/09_41.pdf 